\title{
Seasonal variation in phytoplankton and aquatic plants in floodplain lakes (lower Vistula River, Poland)
}

\author{
Ewa A. Dembowska
}

Received: 21 July 2014 / Accepted: 17 January 2015/Published online: 7 February 2015

(C) The Author(s) 2015. This article is published with open access at Springerlink.com

\begin{abstract}
The study focused on three oxbow lakes which have been isolated from the water of the Vistula River for several years. The diversity of phytoplankton communities was observed biweekly in the growing season (April-October), both in the three floodplain lakes along the lower Vistula River (northern Poland) and in the main current of the river. The water level in the Vistula River remained low, so the lakes were not filled with the surface water of the river. Different phytoplankton communities occurred in the studied lakes compared to the Vistula River. The phytoplankton in the oxbow lakes consisted mainly of small unicellular and colonial flagellates: Cryptomonas, Chlamydomonas, Trachelomonas, and Dinobryon. During the limnophase, only 2-3 species co-dominated, and the reservoirs were in a stable water conditions. The river phytoplankton had both higher diversity and higher abundance compared to the floodplain lakes. In total, 4-8 species co-dominated in the river, usually Chlorococcales and diatoms. The floodplain lakes were characterized by unexpected differences in the quality, quantity, and dynamics of planktonic algae. The differences were strictly associated with the occurrence of macrophytes. During the limnophase, the investigated oxbow lakes were also
\end{abstract}

E. A. Dembowska ( $\square)$

Department of Hydrobiology, Faculty of Biology and

Environmental Protection, Nicolaus Copernicus

University, Lwowska 1, 87-100 Torun, Poland

e-mail: dembow@umk.pl diversified in terms of colonizing plant communities. Different types of vegetation-free floating plants (W-1 lake), communities of submerged macrophytes, free floating plants and algal mats detached from the bottom (W-2 lake), and submerged macrophytes (Ma lake), affected the development of the microflora to a varying extent.

Keywords Abundance $\cdot$ Biodiversity Floodplain lake $\cdot$ Phytoplankton $\cdot$ Vistula River

\section{Introduction}

Floodplains are areas that are periodically flooded with river water (Junk et al. 1989). Hydrological regime is considered as crucial factor of its ecological functioning. Flooded areas are part of a river system due to hydrological contact with the river, but also represent a transition zone between the rivers mainstream and the dry land. The functioning of the riverfloodplain systems depends on the climate, the frequency of flooding, the content of nutrients in the water and sediment, and recently also on human activities (Tockner and Stanford 2002; Ward et al. 2002). This aquatic-terrestrial environment forces various morphological, anatomical, and physiological adaptations in organisms. These habitats also have associated characteristic assemblages of organisms (Junk et al. 1989). 
Many European rivers have been strongly transformed in recent centuries as a result of intensive engineering (Dynesius and Nilsson 1994). The lower section of the Vistula River has also been transformed. The Vistula River is the largest river in the drainage basin of the Baltic Sea. Until the mid-nineteenth century, the Vistula had the nature of a braided river, however, frequent and severe floods made the economic development of these area impossible. The second half of the nineteenth century was a period of extensive engineering of the Vistula, which caused the river lost its natural character. The river engineering primarily required the construction of flood embankments (Makowski 1998) and brought irreversible effects consisting in the loss of a typical river-floodplain system in this area.

The lower Vistula valley is now characterized by a impoverished river-floodplain system. This area was under intensive flood control. Total flooding of this area occurs only during great, catastrophic floods. The water bodies in this area usually do not stay in contact with the waters of the Vistula. Isolation is quite stable and lasts the entire growing season or even a few years. In the natural river valleys, where oxbow lakes have no contact with the river water, the lack of flooding is regarded as a disturbance. Bayley (1995) claims that the flood-pulse is not a disturbance, but rather a temporary discontinuation of the average hydrological regime. Dynamic interactions between water and land are the main processes affecting the production system of the river-floodplain and the biocenosis, and its adaptive processes (Junk et al. 1989). In natural, untransformed conditions, the river valleys are areas that include the current of the river (lotic habitats), flooded ponds and lakes (lenitic habitats), and periodically flooded land areas (Junk et al. 1989). The numerous wetland ecosystems, characteristic of the natural river-floodplain after engineering of the Vistula, are the remaining small oxbow lakes. In the case of the lower Vistula valley, these reservoirs are old riverbeds separated by embankments and largely fragmented. In all cases, these reservoirs remain in contact with the river water during periods of extremely high flooding.

Most frequently, reservoirs remain stagnant waters with low water exchange, except during periods of high water. Such flushing of the floodplain by the river water it is very important in the sustainability of reservoirs. The potamophase causes the so-called refreshing of the reservoir through washing-out of the accumulated bottom sediments. Washing-out of sediments is necessary to maintain a sufficient volume of an oxbow lake. Oxbow lakes are periodically unstable and astatic. During isolation, however, reservoirs become more stable. When there is a low-water level in the river, the reservoirs are not flooded with water from the river, and this conditions are called limnophase (Neiff 1996). Prolonged periods of hydrological drought cause an increase in the importance and the duration of action factors such as: wind dynamics, chemical potential, allelopathic influence of macrophytes, and shading by vegetation or zooplankton pressure (Ibañez 1998; Nabout et al. 2006). During the isolation phase, significant differences can be observed between the planktonic communities of oxbow lakes. Oxbow lakes in this phase may even be compared to shallow macrophyte lakes (Scheffer and Jeppesen 1998; Scheffer and van Nes 2007). In oxbow lakes, competition occurs between phytoplankton and submerged vegetation, and accompanying vascular vegetation mats of filamentous algae-metaphyton (Gross et al. 2007; Irfanullah and Moss 2005).

The first aim of this study was to assess the dynamics of phytoplankton in three neighboring, floodplain lakes of the lower Vistula River valley (central Poland). Each of the three floodplain lakes is isolated from the Vistula River. The second aim was to compare planktonic algal communities in these reservoirs with the algae communities in the river. The research also focused on the development of macrophytes and their possible impact on the phytoplankton community. For several years prior to the research, and in 2007, the water level in the river remained low or at a medium level, which was the cause of the long-term limnophase in oxbow lakes (Kubiak-Wójcicka 2012). Numerous studies indicate that the long-term isolation of oxbow lakes is favorable for the abundant development of Cyanobacteria (e.g. Kasten 2003; Padisák et al. 2003; Izaguirre et al. 2004). The working hypothesis was that the investigated reservoirs is characterized by the dominance of Cyanobacteria, which is different from the river phytoplankton. 


\section{Materials and methods}

Study area

The study focused on the phytoplankton in three small, semi-natural floodplain lakes (Fig. 1) of the lower Vistula located in Torun, Poland: Winnica-1 (W-1), Winnica-2 (W-2) and Martówka (Ma). These reservoirs are shallow $(1.5-2.5 \mathrm{~m})$ and small in area (1.5-3.0 ha). The investigated reservoirs are shallow and diversified in shape; from nearly round to elongated. All oxbow lakes are located near the river. Their distance from the river is below $300 \mathrm{~m}$. Morphometric data of the studied water bodies are included in Table 1. Plankton was analyzed simultaneously on the 732nd $\mathrm{km}$ of the Vistula River.
Fig. 1 Location of the investigated floodplain lakes

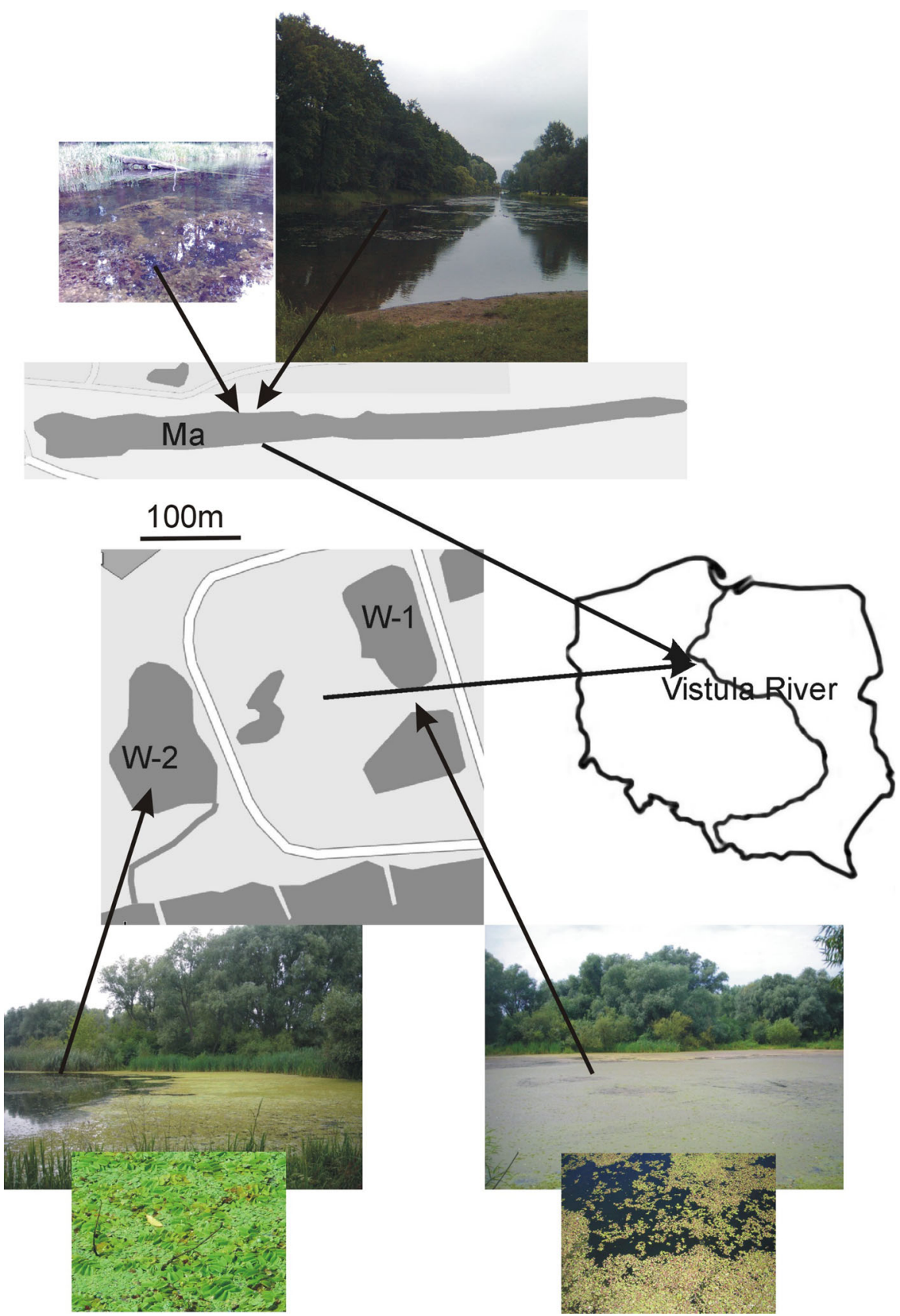


Table 1 Morphometric and physico-chemical data of the water in the floodplain lakes (mean and range)

\begin{tabular}{|c|c|c|c|}
\hline & $\mathrm{W}-1$ & $\mathrm{~W}-2$ & $\mathrm{Ma}$ \\
\hline Longitude & $53^{\circ} 01^{\prime} \mathrm{N}$ & $53^{\circ} 01^{\prime} \mathrm{N}$ & $53^{\circ} 00^{\prime} \mathrm{N}$ \\
\hline Latitude & $18^{\circ} 39^{\prime} \mathrm{E}$ & $18^{\circ} 38^{\prime} \mathrm{E}$ & $18^{\circ} 35^{\prime} \mathrm{E}$ \\
\hline Surface [ha] & 1.5 & 2.0 & 2.8 \\
\hline Maximum depth [m] & 1.8 & 1.6 & 2.5 \\
\hline Maximum length [m] & 140 & 172 & 640 \\
\hline Maximum width [m] & 67 & 103 & 61 \\
\hline $\mathrm{SD}[\mathrm{m}]$ & $1.6(1.4-1.8)$ & $1.2(0.6-1.6)$ & $1.9(1.4-2.5)$ \\
\hline $\mathrm{pH}$ & $7.9(7.6-8.7)$ & $8.0(7.6-8.6)$ & $8.3(7.9-8.8)$ \\
\hline $\mathrm{EC}[\mu \mathrm{S} / \mathrm{cm}]$ & $795(670-860)$ & $930(860-1,000)$ & $650(540-730)$ \\
\hline DO sat. $[\%]$ & $85(40-195)$ & $105(55-165)$ & $80(60-110)$ \\
\hline $\mathrm{DO}[\mathrm{mg} / \mathrm{L}]$ & $7.9(3.6-18.6)$ & $9.6(3.7-15.5)$ & $7.5(5.6-10.5)$ \\
\hline $\mathrm{WT}\left[{ }^{\circ} \mathrm{C}\right]$ & $17.7(13.8-22.3)$ & $19.1(14.1-23.2)$ & $20.2(15.9-23.9)$ \\
\hline $\mathrm{PO}_{4}-\mathrm{P}[\mathrm{mg} / \mathrm{L}]^{\mathrm{a}}$ & $0.126(0.005-0.225)$ & $0.121(0.005-0.245)$ & $0.036(0.005-0.115)$ \\
\hline $\mathrm{N}_{\min }[\mathrm{mg} / \mathrm{L}]^{\mathrm{a}}$ & $0.633(0.240-1.134)$ & $0.928(0.291-1.391)$ & $0.439(0.331-0.595)$ \\
\hline Trophic State Index SD [TSI $\left.{ }_{\mathrm{SD}}\right]$ & $53(55-52)$ & $58(67-53)$ & $51(55-47)$ \\
\hline Phytoplankton abundance $\left[10^{6} \mathrm{ind} / \mathrm{L}\right]$ & 2.470 & 8.415 & 1.386 \\
\hline
\end{tabular}

$\mathrm{N}_{\text {min }}=\mathrm{NH}_{4}-\mathrm{N}+\mathrm{NO}_{2}-\mathrm{N}+\mathrm{NO}_{3}-\mathrm{N}$

a Values from 2008 to 2009 years

\section{Sampling methods}

The research material was collected in the middle of every oxbow, at one point. For comparison, water was also collected from the Vistula. The Vistula water sampling position was located at the 732nd $\mathrm{km}$ mark of the river. Samples were collected every two weeks from April to October 2007. The selected physicochemical parameters determined in the water were as follows: Secchi disc visibility $(\mathrm{SD}, \mathrm{m}), \mathrm{pH}$, oxygen concentration and saturation (DO, mg/L; DO sat., \%), and electrolytic conductivity (EC, $\mu \mathrm{S} / \mathrm{cm})$. Measurements of physico-chemical parameters were performed by Multi 3430 SET F WTW field probes. Water for analyses of the orthophosphates, nitrates, nitrites, and ammonium content was collected once a month in 2008-2009 years. Standard methods of chemical analysis were applied (Hermanowicz et al. 1999).

For qualitative analyses, material was collected from the water column with a plankton net. The diameter of the net mesh was $25 \mu \mathrm{m}$. For quantitative analyses, $100 \mathrm{ml}$ of water was collected from a depth of ca. $0.5 \mathrm{~m}$. This material was not concentrated. Phytoplankton samples were fixed in acetic Lugol's solution ( $\mathrm{J}$ in $\mathrm{KJ})$. A total of 40 phytoplankton samples were collected during the investigated period.

Quantitative assessment was done according to the Utermöhl method (1958). The trophic state index (TSI) was calculated based on the Secchi disc visibility (Carlson 1977). The dominant species described in this paper, with abundance above $5 \%$, were classified into functional groups (Fgs) based on the studies by Reynolds et al. (2002), Reynolds (2006), and updated by Padisák et al. (2009). Pearson's simple correlation (MS Excel) was applied to analyze the relationships between phytoplankton communities (as a number of species and abundance) and environmental conditions. To assess the similarity between phytoplankton species composition (Jaccard's coefficient) and species diversity (Simpson, ShannonWiener, evenness), a multivariate statistical package was used-MVSP 3.2.

All data set was compared by direct ordination method. Redundancy analysis (RDA) was used because the length of gradient in the data set checked in DCA ordination was ca 2.9 SD (ter Braak and Šmilauer 2002; Jongman et al. 1995). In the RDA ordination all samples were included and following environmental parameters: EC, DO sat., pH, WT. Due 
to the multi- function of variable DO and VIF $>20$, DO was removed from the analysis. Species data were $\log$ transformed $(\log (\mathrm{A}+1)$; ter Braak and Šmilauer 2002). To assess relative importance and statistical significance of environmental factors in differentiation of investigated stands forward selection procedure and Monte Carlo permutation test were applied. For ordination CANOCO 4.5 package was used (ter Braak and Šmilauer 2002).

\section{Results}

\section{Environmental characteristics}

During the whole study period, the oxbow lakes were isolated from the Vistula waters. The average water level in the Vistula River at the time of sample collection was $229 \mathrm{~cm}$. The water level in the Vistula River remained at a low level. The highest water level in the Vistula River was $397 \mathrm{~cm}$ and occurred on September 14. This level was almost $250 \mathrm{~cm}$ lower than the state of emergency for Torun $(650 \mathrm{~cm})$. Such a water level in the Vistula River did not cause flooding.

The studied oxbows were diverse in terms of some environmental conditions, such as water temperature, transparency, oxygen concentration and electrolytic conductivity. Ma lake had the greatest transparency and the bottom of the reservoir could be seen a few times. The correlation between the transparency of water and abundance of phytoplankton was negative and very strong $(r=-0.94, p<0.05)$ in this reservoir.

In the other reservoirs, water transparency was significantly lower. The lowest visibility SD (Table 1), i.e. just $0.6 \mathrm{~m}$, was recorded on July 24 in $\mathrm{W}-2$. The classification of the trophic status of these reservoirs was conducted on the basis of transparency. All oxbow lakes are eutrophic. The lowest mean value of $\mathrm{TSI}_{\mathrm{SD}^{-}}-51$ was found in the Ma reservoir, while the highest mean value of 58 was found in the oxbow lake W-2.

Electrolytic conductivity was very high and ranged from $650 \mu \mathrm{S} / \mathrm{cm}$ in $\mathrm{Ma}$ to $930 \mu \mathrm{S} / \mathrm{cm}$ in the oxbow lake $\mathrm{W}-2$. The reservoirs had similar alkaline $\mathrm{pH}$; about 8.0. The alkaline $\mathrm{pH}$ had a significant positive correlation with the oxygen concentration and saturation $(r=0.65, r=0.67, p<0.05)$. In all the reservoirs, oxygen saturation of the surface layer was high and many times exceeded $100 \%$. In this way, hypersaturation was provided. The oxygen content in the surface layer showed a very strong correlation with saturation $(r=0.99, p<0.05)$. Values of all physical and chemical parameters are presented in Table 1.

Phytoplankton

A total of 305 taxa were identified in the phytoplankton composition of the oxbow lakes and in the Vistula. The highest species similarity was determined for the phytoplankton of the Vistula (Jaccard's coefficient from 0.404 to 0.575 ). The species composition of the oxbow lakes was significantly different from the plankton of the Vistula (Fig. 2). Plankton in the reservoirs W-1, W-2 and Ma significantly varied. Species composition in the Ma lake was different compared to the Vistula and oxbow lakes $\mathrm{W}-1$ and $\mathrm{W}-2$. There was a unique assemblage of species in the $\mathrm{W}-1$ and W-2 reservoirs. The similarity between samples, however, was low and ranged from 0.181 to 0.375 (Jaccard's coefficient).

A total of 145 taxa were identified in the W-1 oxbow lake, including mostly diatoms - 72 and Chlorophyta-41 (Table 2). The average abundance of phytoplankton in $\mathrm{W}-1$ was 2.470 ind./L $10^{6}$. The highest value of abundance was 13.182 ind./L $10^{6}$, recorded in April-May before the water surface was covered with the free floating plants. In April, Cryptophyta, Euglenophyta (Trachelomonas volvocinopsis), and diatoms-Cyclotella meneghiniana, and Fragilaria ulna var. acus co-dominated (Fgs W2/C/Y/D) (Table 3). In May when the spring bloom appeared, the dominant taxon of Chrysophyceae, i.e. Dinobryon sertularia (84\%) also appeared (Fg E). In June, small coccal green algae, mainly Desmodesmus communis $(\mathbf{X 1 /} / \mathbf{J} / \mathbf{F})$, dominated in the phytoplankton. Cryptomonads $(\mathrm{Fg} \mathbf{Y})$ frequently appeared in the second half of June, and they dominated in this reservoir from July till the end of the study period (Fig. 3A).

A total of 130 taxa were identified in the phytoplankton composition of the W-2 oxbow lake, including the dominant diatoms-50 taxa and Chlorophyta -44 taxa (Table 2). The average abundance of phytoplankton in W-2 was 8.415 ind./L $10^{6}$. The maximum number of phytoplankton with water bloom characteristics was 35.785 ind./L $10^{6}$ and it was recorded in spring (Fig. 3B). In the reservoir $\mathrm{W}-2$, the 
Fig. 2 Similarity of phytoplankton species composition in the oxbow lakes and the Vistula River

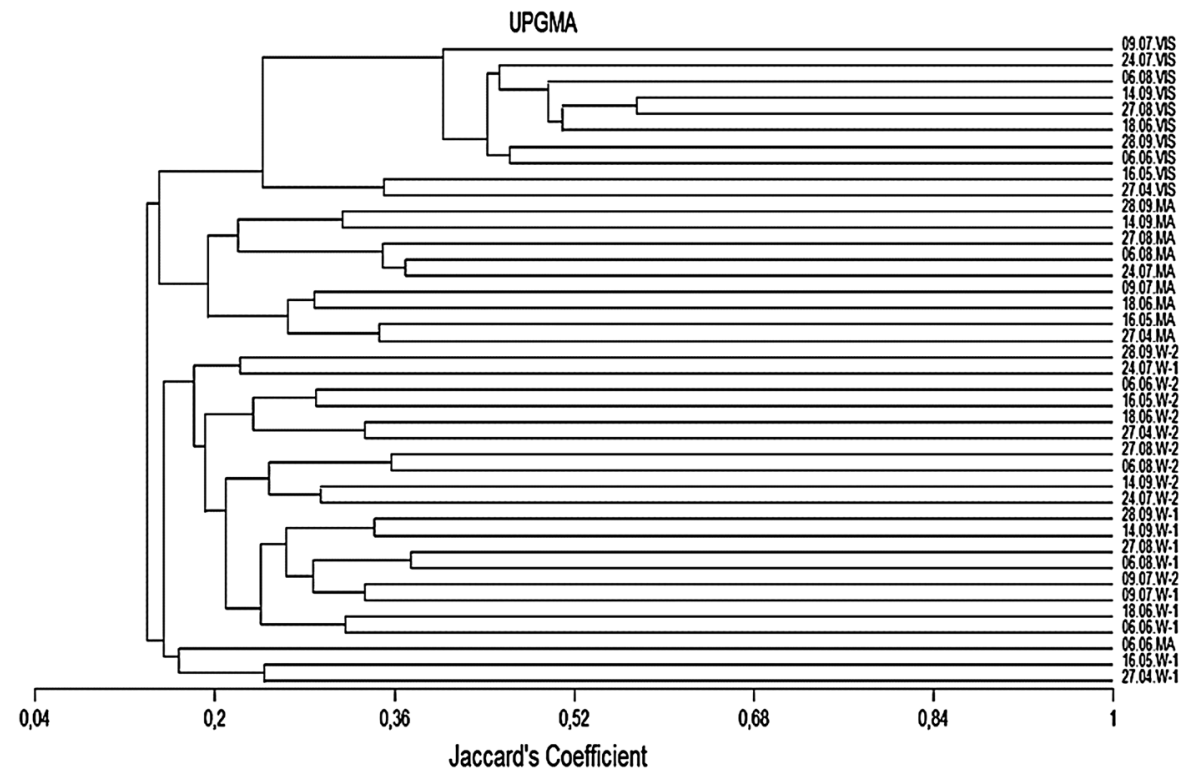

Table 2 Phytoplankton diversity indices in the floodplain lakes

\begin{tabular}{lllll}
\hline Station & Simpson's & Shannon-Wiener & Evenness & Number of species \\
\hline W-1 & $0.49(0.25-0.82)$ & $1.14(0.61-1.9)$ & $0.32(0.17-0.50)$ & $145(22-49)$ \\
W-2 & $0.39(0.17-0.59)$ & $0.84(0.55-1.55)$ & $0.25(0.12-0.43)$ & $130(14-57)$ \\
Ma & $0.53(0.30-0.73)$ & $1.17(0.82-1.69)$ & $0.34(0.23-0.55)$ & $143(13-60)$ \\
Vis & $0.88(0.60-0.94)$ & $2.75(1.54-3.36)$ & $0.65(0.45-0.75)$ & $189(30-97)$ \\
\hline
\end{tabular}

most intensive development of phytoplankton was observed. There was a significant correlation between the abundance of phytoplankton and oxygen concentration $\mathrm{r}=0.74, \mathrm{p}<0.05$. In April and May, the phytoplankton was dominated almost exclusively by centric diatoms (Fg C) Cyclotella meneghiniana (Table 3). In early June, cryptomonads (Fg Y) frequently occurred. From July to mid-September, centric diatoms co-dominated with cryptomonads $(\mathbf{C} / \mathbf{Y})$. At the end of September, phytoplankton was dominated by the colonial Chrysophyceae from the genus Uroglena $(\mathbf{U})$.

A total of 143 taxa were identified in the phytoplankton of Ma, including mostly diatoms - 58 and Chlorophyta -45 . The phytoplankton abundance in Ma was many times lower compared to other reservoirs and the Vistula (Fig. 3C). The average abundance of phytoplankton in Ma was 1.396 ind./L $10^{6}$. Cryptomonads dominated throughout the season (Y). During the spring and early summer, Cryptomonads co-dominated with diatoms, green algae, Chrysophyceae, and Euglenophyta (Fgs X1, P, C, E, W2).
During the late summer and autumn, cryptomonads co-dominated only with Chlorococcales (Y/X1) (Table 3). Phytoplankton in the oxbow lake Ma developed most intensively in the summer period, from June through August. The maximum abundance of 2.614 ind./L $10^{6}$ was recorded in the second half of June, and abundance which was close to the maximum value persisted till the end of July.

The phytoplankton in all the Vistula River oxbow lakes showed a negative correlation with water transparency $(r=-0.68)$. A positive correlation occurred between the abundance of phytoplankton and the concentration of oxygen $(r=0.60, p<0.05)$, and oxygen saturation $(\mathrm{r}=0.58, \mathrm{p}<0.05)$.

The largest number of algae species was determined in the phytoplankton of the Vistula. There were 189 taxa, most of which were green algae -75 and diatoms - 72. The average abundance of phytoplankton in the Vistula was 8.329 ind./L $10^{6}$. Diatoms (C/D/ P) co-dominated with the coccal green algae $(\mathbf{X 1 / J} / \mathbf{F})$ throughout the season (Table 3; Fig. 3D). Occasionally, in late spring and summer, also Cryptophyta 


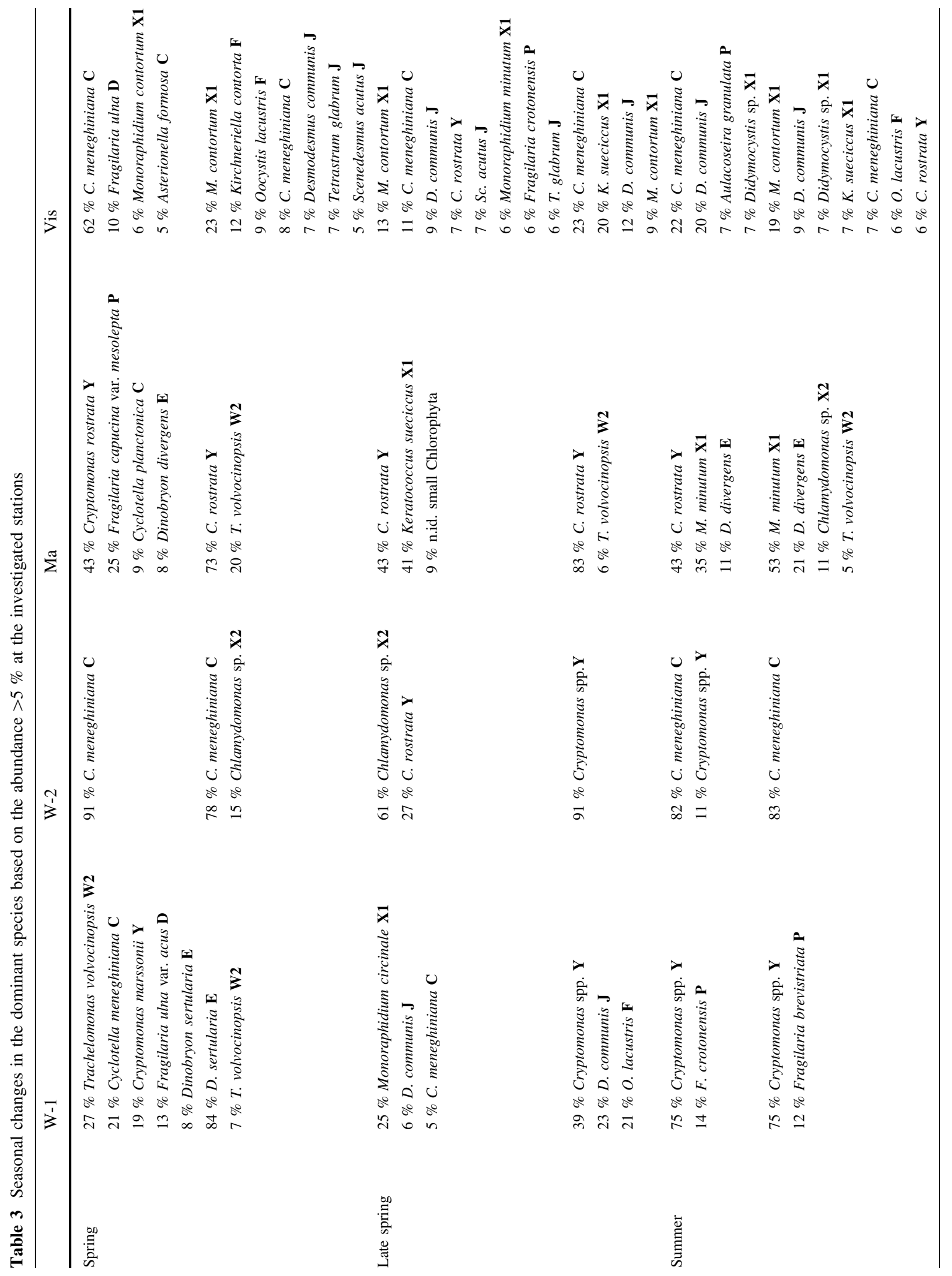




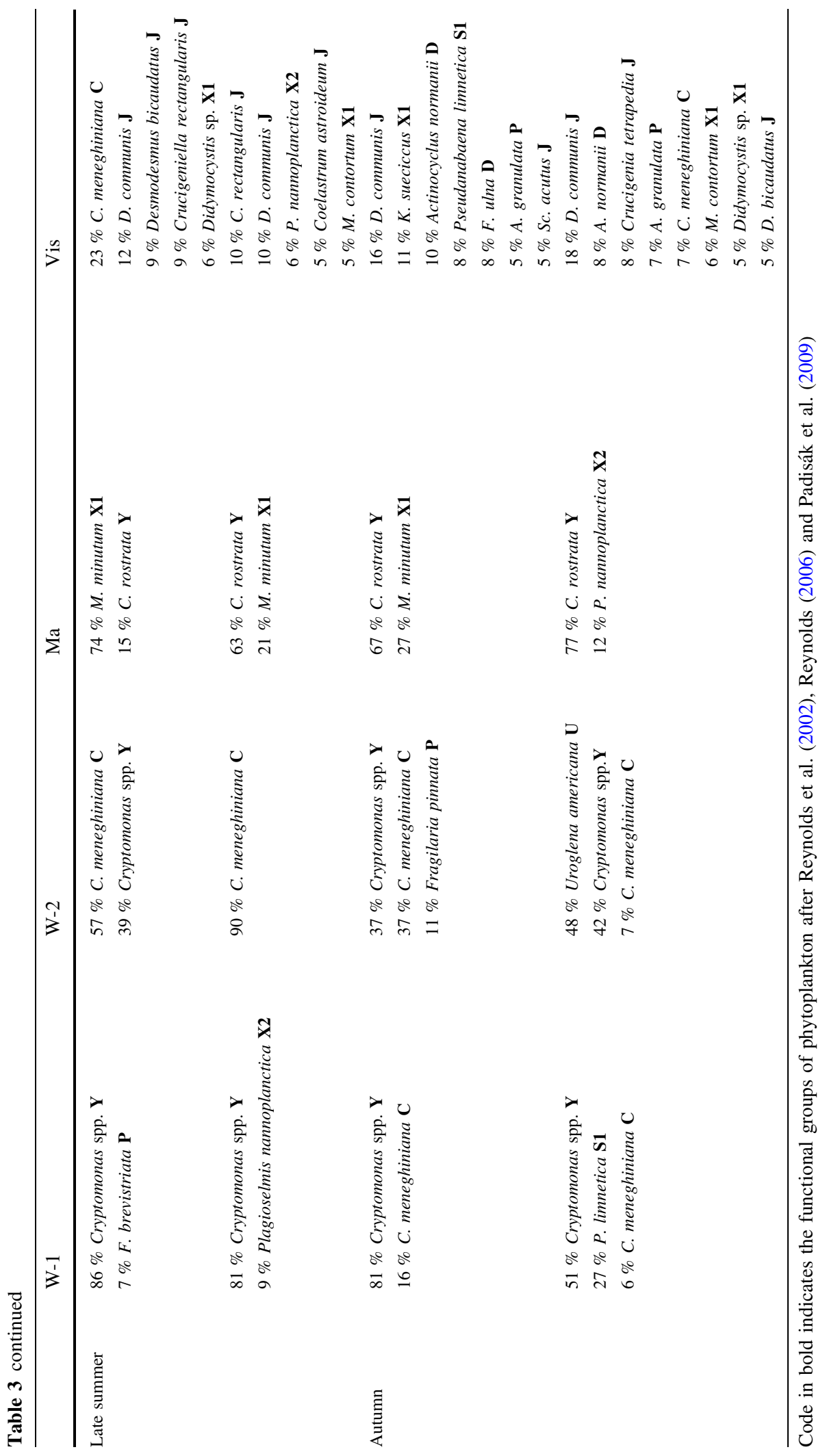


Fig. 3 Seasonal variation of the phytoplankton abundance $\left(10^{6} \mathrm{ind} / \mathrm{L}\right)$ and macrophyte cover in the oxbow lakes and the main channel of the Vistula in the limnophase : A W-1; B W-2; C Ma; D Vis
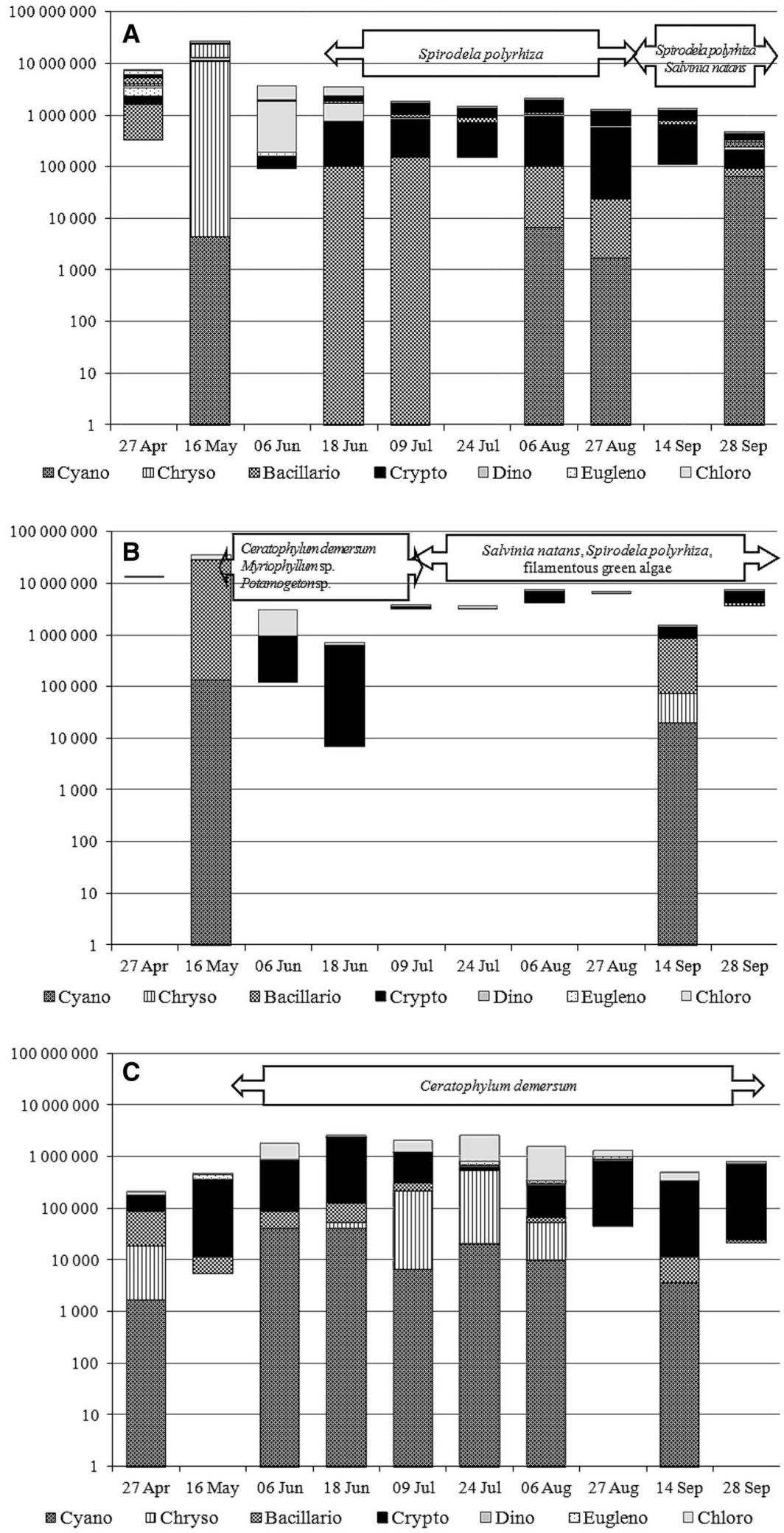
Fig. 3 continued

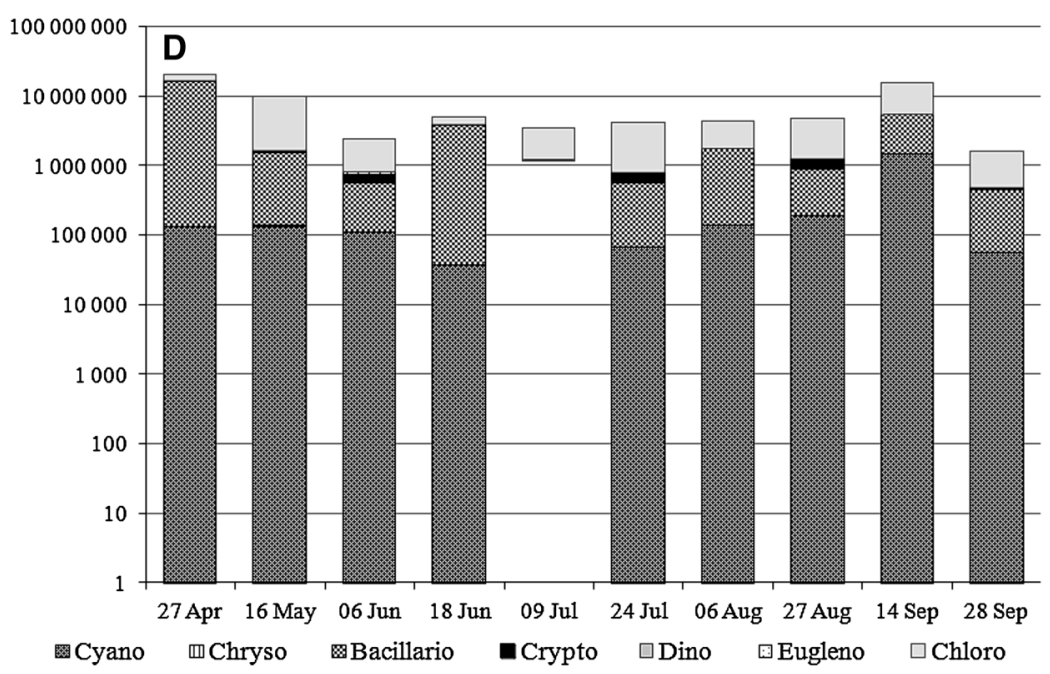

(Y) occurred. The maximum number of phytoplankton-21.197 ind./L $10^{6}$ was recorded in April. The second quantitative peak was recorded in autumn. There was a significant correlation between the water level and abundance of phytoplankton $(r=0.62$, $\mathrm{p}<0.05)$.

Multivariate analysis of environmental

Redundancy analysis (RDA) were based on data on the individuals density and environmental variables for phytoplankton in oxbows and main channel of Vistula River (Fig. 4). EC is only one variable significant differentiating communities. This parameter was the highest in the samples from the position of $\mathrm{W}-2$ and explains $11 \%$ of the variation of the total set.

Cryptophyta (Cryptomonas erosa) and some of diatoms were positively correlated with conductivity. Other parameters and the presence of most species showed no statistically significant variation.

\section{Macrophytes}

In each of the reservoirs, a different type of vascular vegetation developed (Fig. 3A-C). At the beginning of June, vascular vegetation appeared and started to cover the water surface in the $\mathrm{W}-1$ reservoir. The freefloating plants initially occurred at the shore and occupied about $25 \%$ of the surface of the lake. In July covered was over $50 \%$ of lake surface, and the water surface was completely covered (100\%) from August to end of growing season. The free-floating plants included: Spirodela polyrhiza (L.) Schleid., Salvinia natans (L.) All., and Lemna minor L. In the W-2 oxbow lake, submerged macrophytes - Ceratophyllum demersum L., Myriophyllum spicatum L. and Potamogeton occurred in the early stages of vascular vegetation. Submerged plants were covered the entire surface of the bottom, but not to densely (circa $50 \%$ of the bottom). On submerged plants occurred filamentous algae that breaking off and also floated a surface of lake. In June, free floating plants, mainly Salvinia natans occurred. Initially, these pleustophytes occurred only at the shore $(20 \%)$ but from August to October, they covered almost the entire water surface (about $95 \%$ ). In Ma, the bottom of the reservoir was densely covered with Ceratophyllum demersum $\mathrm{L}$. At the beginning of the growing season the plants occupy about $50 \%$ of the bottom. From June the bottom was covered in $100 \%$. Development of Ceratophyllum was so strong that there was densely vegetation near the surface. Only the areas close to the shore were free of submerged vegetation.

Chrysophyceae (Dinobryon) dominated in phytoplankton where the coverage was low $(<25 \%$, only in $\mathrm{W}-1)$. Chlorophyta dominated when about $25 \%$ of the surface was covered. Small centric diatoms were characteristic at $50 \%$ coverage. When macrophyte covered almost the entire water surface diatoms, green algae and Cryptophyta dominated in phytoplankton (Fig. 5). 

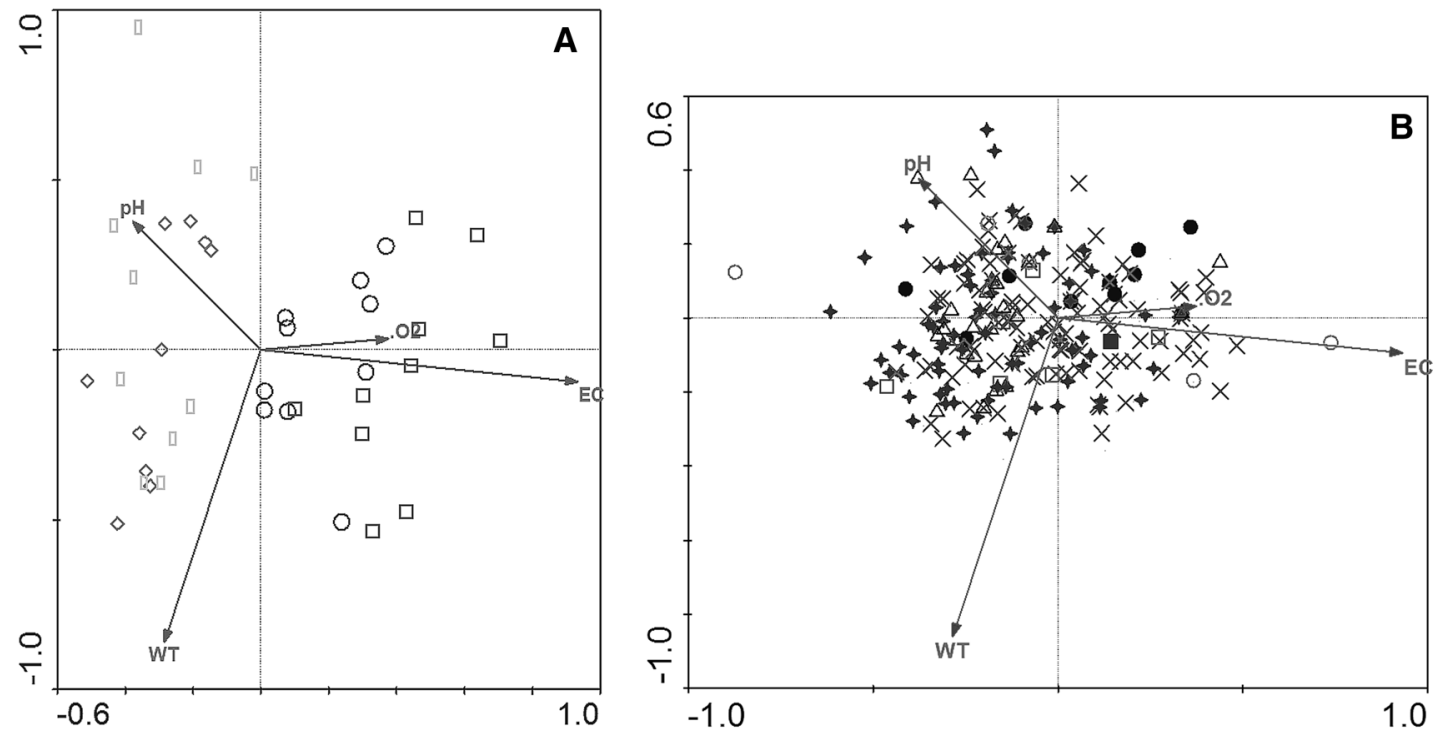

\section{SPECIES}

$\triangle$ Cyanobacteria $\times$ Bacillariophyceae + Chlorophyta Euglenophyta

Chrysophyceae $\bigcirc$ Cryptophyta

Xantophyceae

Dinophyta ENV. VARIABLES

$\rightarrow$

SAMPLES

$\bigcirc$ W-1 $\square$ W-2 $\diamond$ MA $\quad \square \quad$ Vl

Fig. 4 Redundancy analysis (RDA) based on data on the individuals density and environmental variables for phytoplankton in oxbows and main channel of Vistula River. Significant variables (Monte Carlo permutation test, $\mathrm{p}<0.002$ ). A Analysis of physico-chemical parameters and stations, $\mathbf{B}$ relationship between physico-chemical parameters and abundance of plankton species

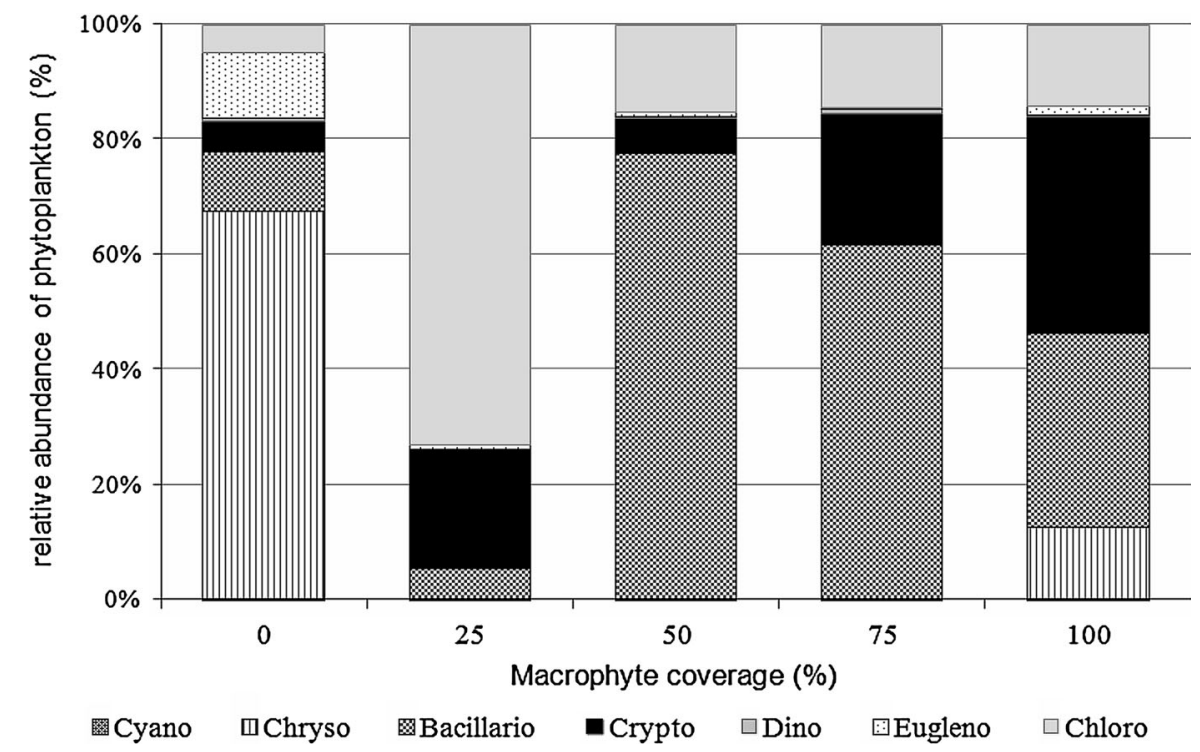

Fig. 5 Relative average abundance of phytoplankton along the different macrophyte coverage 


\section{Discussion}

Due to the persistent low water in the Vistula River in 2007 , all of the oxbow lakes were isolated from the mainstream of the river. There was a hydrological drought in Poland from 2003. The drought caused the development of different phytoplankton communities in the floodplain compared to the communities in the main course of the Vistula River. The prolonged separation of the reservoirs, resulted in clearly different types of phytoplankton found in these water bodies.

In terms of oxygen conditions and the development of macrophytes, the investigated reservoirs were similar to shallow eutrophic lakes (Scheffer and Jeppesen 1998). On the surface, a hypersaturation phenomenon was often observed, associated with intense photosynthesis of abundantly growing phytoplankton and submerged macrophytes.

The free floating plants - Spirodela polyrhiza, Lemna minor and Salvinia natans were present on the water surface of the neighboring oxbow lakes W-1 and $\mathrm{W}-2$ from the beginning of June 2007. Initially, the development of phytoplankton went undisturbed, hence algal blooms were observed in spring. In good light conditions, the development of phytoplankton (as abundance and biomass) is intense and many times higher compared to the presence of the free floating plant cover (O'Farrell et al. 2009). In W-1, the water bloom was formed by Dinobryon sertularia. Chrysophyta may occur in shallow mixed reservoirs and quickly replace drooping diatoms (Diaz et al. 1998). Algae of the genus Dinobryon are important phagotrophs capable of absorbing fine particles and may be important in the elimination of bacterioplankton. Probably the W-1 reservoir belongs to heterotrophic lakes which offer a good habitat for Dinobryon (Padisák et al. 2009). The long-lasting limnophase favors the accumulation and decomposition of organic matter originating from the previous years' vegetation. It seems that in $\mathrm{W}-1$, high fertility, stability of the water mass, and alkaline $\mathrm{pH}$, should be conducive to the accumulation of cyanobacteria. Perhaps the overabundance of decomposing organic matter, as well as the effect of decomposing barley straw, causes a poor development of blue-green algae in this reservoir. This supposition for low abundance of Cyanobacteria gives Pithart et al. (2007) in the small oxbow lakes of the Lužnice River.
In $\mathrm{W}-2$, spring phytoplankton was dominated by centric diatoms $(\mathrm{Fg} \mathbf{C})$ that are characteristic of small water reservoirs with no stratification (Reynolds et al. 2002; Reynolds 2006; Padisák et al. 2003, 2009). Centric diatoms belonging to $\mathrm{Fg} \mathbf{C}$ are also characteristic of phytoplankton in many rivers, including the Vistula (Dembowska 2009; Kentzer et al. 2010), and the Danube (Mihaljević et al. 2010). The presence of these algae during the limnophase in the W-2 oxbow lake indicates that in $\mathrm{W}-2$, diatoms found a good location for further development.

As a consequence of an increase in the floating vegetation, the phytoplankton communities of both reservoirs collapsed. The presence of cover on the surface of the reservoir is a stressor for phytoplankton, reduces the availability of light which prevents photosynthesis, and limits the growth of algal populations. As a result, there is a modification of environmental conditions, especially a decrease in the oxygen concentration. Under a layer of floating vegetation, cryptomonads may develop almost exclusively. Cryptomonads (Fg Y) are present (Reynolds et al. 2002; Reynolds 2006; Padisák et al. 2009), and predominate in waters with low light availability. Cryptomonads are also able to better capture nutrients because of their ability to mixotrophy (Jones 2000). Dominant Cryptophyta are common in many oxbow lakes (Paidere et al. 2007; Pithart et al. 2007; BovoScomparin and Train 2008; Krasznai et al. 2010), which may be due to their high tolerance to different trophic conditions and resistance to shade in the water column. Cryptomonads are very sensitive to predation by zooplankton communities (Reynolds et al. 2002; Reynolds 2006; Padisák et al. 2009). Cryptomonads in the W-2 reservoir were accompanied by small singlecelled diatoms that also tolerate the lack of light.

Contrary to expectations, there was no dominance of Cyanobacteria in any of the studied reservoirs, despite the fact that Cyanobacteria often cause water blooms in eutrophic lakes (Pełechata et al. 2006; Dembowska 2011; Kobos et al. 2013) and some of the oxbow lakes (Bovo-Scomparin and Train 2008; Mihaljević et al. 2009, 2010; Krasznai et al. 2010; Mihaljević and Stević 2011; Dembowska et al. 2012). Mihaljević et al. (2009) proved that limited mixing of water encountered in the limnophase is the main cause of cyanobacterial blooms in oxbow lakes. In the W-1 reservoir, only Pseudanabaena limnetica (Fg S1) was more abundant in the autumn. In the $\mathrm{W}-1$ reservoir, in 
contrast to W-2 and Ma, submerged macrophytes covered only a narrow strip at the reservoir's shore. Krasznai et al. (2010) reported that the dominance of bloom-forming Cyanobacteria occurs in oxbow lakes which have a small number of macrophytes $(<40 \%)$ covering the bottom of such lakes.

In the studied oxbow lakes, macrophytes were one of the main factors affecting the communities of algae. In the water bodies where dominant macrophytes are observed, usually there is a strong competition for the resources of nutrients, light, and allelopathy observe (van Donk et al. 1993; Scheffer and Jeppesen 1998; Gross et al. 2007). Ma is an example of such reservoirs. The lowest phytoplankton abundance was recorded in the submerged vegetation (Ceratophyllum demersum) of Ma. There was no statistically significant correlation between the number of phytoplankton and the concentration of oxygen in the water of the Ma reservoir. This lack of correlation indicates that the submerged vegetation plays the main role as a producer. Except for directly limiting phytoplankton, submerged macrophytes are a substrate for periphyton and a hiding place for filtering zooplankton (van Donk and van de Bund 2002; Muylaert et al. 2006). In the Ma reservoir, zooplankton probably also play an important role in the phytoplankton control. Studies by Napiórkowski (2009) indicate over $80 \%$ contribution of Cladocera in the zooplankton biomass of the Vistula's oxbow lakes. A high transparency was observed in Ma throughout the study period, indicating that this reservoir remained in a clear-water phase. This phenomenon often occurs in shallow lakes (Scheffer and Jeppesen 1998).

The phytoplankton in the Vistula River was much richer compared to the oxbow lakes, in terms of the number of species and the number of co-dominants. The average abundance was similar to the value recorded for the Ma oxbow lake. However, the river phytoplankton dynamics was different since there were two peaks of development. The low and moderate water-level indicated that phytoplankton growth had the most optimal conditions. There is a statistically significant correlation between the water level and abundance of phytoplankton. The high water level in a river during floods negatively affects the development of the river phytoplankton through a few interrelated factors: the large amount of suspension, low water transparency and the current velocity that prevents cell multiplication (Dembowska 2002; Mihaljević et al. 2009). The phytoplankton composition of the Vistula is distinguished by the presence of many species of Chlorococcales and Bacillariophyceae which are typical for shallow turbid waters with enriched conditions (Reynolds et al. 2002; Reynolds 2006; Padisák et al. 2009).

Low biodiversity in the studied oxbow lakes (Table 3) compared to the Vistula is caused by a strong dominance of a few species (mostly 2-3 species) the during limnophase. These results indicate the negative impact of the limnophase on the phytoplankton community. This effect was most obvious at the W-2 station where all indicators of the species diversity and the number of species had the lowest values, while the abundance had the highest value of all the oxbow lakes.

\section{Summary and conclusions}

The research in 2007 dealt with the species composition of phytoplankton in shallow floodplain lakes. The lakes had experienced long-term isolation from the Vistula River. All of the results indicated a stabilization of the ecological conditions in the lakes. Extremely low phytoplankton abundance characterized the clear state. The long-lasting isolation was not a stress factor for phytoplankton development in the these lakes.

To conclude, the limnophase in oxbow lakes is stable water conditions, whereas the river is a dynamic environment. The disorder caused high biodiversity. The continuous disturbances are natural to rivers and the driving force for the ever-changing co-dominants. Species occurring in the river must continuously adapt to unstable conditions, and the rate of biodiversity is quite high. This rate is a reflection of co-dominance of many species. In the neighboring W-1 and W-2 lakes, the development of phytoplankton was undisturbed in the springtime when algal blooms occurred. From the beginning of June in the W-1 and W-2 lakes, freefloating plants covered the water surface which limited the growth of algal populations The lowest abundance of phytoplankton was recorded in the Ma lake with abundant submerged vegetation. There was no dominance of Cyanobacteria in any of the studied reservoirs.

Open Access This article is distributed under the terms of the Creative Commons Attribution License which permits any use, distribution, and reproduction in any medium, provided the original author(s) and the source are credited. 


\section{References}

Bayley PB (1995) Understanding large river-floodplain ecosystems. Significant economic advantages and increased biodiversity and stability would result from restoration of impaired systems. Bioscience 45(3):153-158

Bovo-Scomparin VM, Train S (2008) Long term variability of the phytoplankton community in an isolaterd floodplain of the Ivinhema River State Park, Brazil. Hydrobiologia 610:331-344

Carlson RE (1977) A tropic state index for lakes. Limnol Oceanogr 22:361-369

Dembowska E (2002) Fitoplankton zbiornika Włocławskiego w latach 1994-2000, Ph.D. thesis

Dembowska E (2009) Phytoplankton species diversity of the Lower Vistula from Wyszogród to Toruń. Oceanol Hydrobiol Stud 38:63-74

Dembowska E (2011) Cyanobacterial blooms in shallow lakes of the Iławskie Lakes District. Limnol Rev 11(2):69-79

Dembowska E, Głogowska B, Dąbrowski K (2012) Dynamics of algae communities in the oxbow lake (Vistula River, Poland). Arch Pol Fish 20:27-37

Diaz M, Pedrozo FL, Temporetti PF (1998) Phytoplankton of two Arauncanian lakes of differing tropic status (Argentina). Hydrobiologia 369(370):45-57

Dynesius M, Nilsson C (1994) Fragmentation and flow regulation of river systems in the northern third of the world. Science 266:753-762

Gross EM, Hilt S, Lombardo P, Mulderij G (2007) Searching for allelopathic effects of submerged macrophytes on phytoplankton-state of art and open questions. Hydrobiologia 584:77-88

Hermanowicz W, Dojlido J, Dożańska W, Koziorowski B, Zerbe J (1999) Physico-chemical investigations of water and sewages. Arkady, Warszawa $556 \mathrm{p}$

Ibañez M-SR (1998) Phytoplankton composition and abundance of a central Amazonian floodplain lake. Hydrobiologia 362:79-83

Irfanullah HM, Moss B (2005) Allelopathy of filamentous green algae. Hydrobiologia 543:169-179

Izaguirre I, O'Farrell I, Unrein F, Sinistro R, dos Santos Afonso M, Tell G (2004) Algal assemblages across a wetland, from a shallow lake to relictual oxbow lakes (Lower Parana River, South America). Hydrobiologia 511:25-36

Jones RJ (2000) Mixotrophy in planktonic protists: an overview. Freshw Biol 45:219-226

Jongman RHG, ter Braak CJF, van Tongeren DFR (eds) (1995) Data analysis in community and landscape ecology. Pudoc, Wageningen

Junk W, Bayley PB, Sparks RE (1989) The flood pulse concept in river floodplain system. Can Spec Publ Fish Aquat Sci 106:110-127

Kasten J (2003) Inundation and isolation: dynamics of phytoplankton communities in seasonal inundated flood plain waters of the Lower Odra Valley National Park-Northeast Germany. Limnologica 33:99-111

Kentzer A, Dembowska E, Giziński A, Napiórkowski P (2010) Influence of the Włocławek Reservoir on hydrochemistry and plankton of a large, lowland river (the lower Vistula River, Poland). Ecol Eng 36:1747-1753
Kobos J, Błaszczyk A, Hohlfeld N, Toruńska-Sitarz A, Krakowiak A, Hebel A, Sutryk K, Grabowska M, Toporowska M, Kokociński M, Messyasz B, Rybak A, NapiórkowskaKrzebietke A, Nawrocka L, Pełechata A, Budzyńska A, Zagajewski P, Mazur-Marzec H (2013) Cyanobacteria and cyanotoxins in Polish freshwater bodies. Oceanol Hydrobiol Studies 42(4):358-378

Krasznai E, Borics G, Várbíró G, Abonyi A, Padisák J, Deák C, Tóthmérész B (2010) Characteristics of the pelagic phytoplankton in shallow oxbows. Hydrobiologia 639:173-184

Kubiak-Wójcicka K (2012) Charakterystyka niżówek na Wiśle w Toruniu. The characteristics of low water levels on the Vistula river in Torun. In: Marszelewski W (ed) Gospodarowanie wodą w warunkach zmieniającego się środowiska, vol 1. Monografie Komisji Hydrologicznej PTG T, Lubin, pp 85-93

Makowski J (1998) Wały przeciwpowodziowe dolnej Wisły, historyczne kształtowanie, obecny stan i zachowanie w czasie znacznych wezbrań. Część druga: odcinek od Torunia do Białej Góry. Wydawnictwo Instytutu Budownictwa Wodnego PAN, Biblioteka Naukowa Hydrotechnika

Mihaljević M, Stević F (2011) Cyanobacterial blooms in a temperate river-floodplain ecosystem: the importance of hydrological extremes. Aquat Ecol 45:335-349. doi:10. 1007/s10452-011-9357-9

Mihaljević M, Stević F, Horvatić J, Hackenberger Kutuzović B (2009) Dual impact of the flood pulses on the phytoplankton assemblages in a Danubian floodplain lake (Kopački Rit Nature Park, Croatia). Hydrobiologia 618:77-88

Mihaljević M, Špoljarić D, Stević F, Cvijanović V, Hackenberger Kutuzović B (2010) The influence of extreme floods from the River Danube in 2006 on phytoplankton communities in a floodplain lake: shift to a clear state. Limnologica 40:260-268

Muylaert K, Declerck S, van Wichelen J, De Meester L, Vyverman W (2006) An evaluation of the role of Daphnids in controlling phytoplankton biomass in clear water versus turbid shallow lakes. Limnologica 36:69-78

Nabout JC, Nogueira IS, Oliveira LG (2006) Phytoplankton community of floodplain lakes of the Araguaia River, Brazil, in the rainy and dry seasons. J Plankton Res 28(2):181-193

Napiórkowski P (2009) Influence of hydrological conditions on zooplankton of oxbow lakes (old riverbeds) of the Lower Vistula in the city of Toruń. Limnol Papers 4:55-67

Neiff JJ (1996) Large rivers of South América: toward the new approach. Verh Internat Verein Limnol 26:167-180

O'Farrell I, de Tezanos Pinto P, Rodriguez P, Chaparro G, Pizarro H (2009) Experimental evidence of the dynamic effect of free-floating plants on phytoplankton ecology. Freshw Biol 54:363-375

Padisák J, Borcis G, Fehér G, Grigorszky I, Oldal I, Schmidt A, Zámbone-Doma Z (2003) Dominant species, functional assemblages and frequency of equilibrium phases in late summer phytoplankton assemblages in Hungarian small shallow lakes. Hydrobiologia 502:157-168

Padisák J, Crossetti LO, Naselli-Flores L (2009) Use and misuse in the application of the phytoplankton functional 
classification: a critical review with updates. Hydrobiologia 621:1-19

Paidere J, Gruberts D, Škute A, Druvietis I (2007) Impact of two different flood pulses on planktonic communities of the largest floodplain lakes of the Daugava River (Latvia). Hydrobiologia 592:303-314

Pełechata A, Pełechaty M, Pukacz A (2006) Cyanoprokaryota of shallow lakes of Lubuskie Lakeland (mid-western Poland). Oceanol Hydrobiol Studies 35(1):3-14

Pithart D, Pichlová R, Bílý M, Hrbáček J, Novotná K, Pechar L (2007) Spatial and temporal diversity of small shallow waters in river Lužnice floodplain. Hydrobiologia 584:265-275

Reynolds CS (2006) Ecology of phytoplankton. Cambridge University Press, Cambridge, pp 327-341

Reynolds CS, Huszar V, Kruk C, Naselli-Flores L, Melo S (2002) Towards a functional classification of the freshwater phytoplankton. J Plankton Res 24(5):417-428

Scheffer M, Jeppesen E (1998) Alternative stable state. In: Scheffer M (ed) Ecology of shallow lakes. Chapman and Hall, London, p 357

Scheffer M, van Nes E (2007) Shallow lakes theory revisited: various alternative regimes driven by climate, nutrients, depth and lake size. Hydrobiologia 584:455-466 ter Braak CJF, Šmilauer P (2002) CANOCO reference manual and user's guide to Canoco for Windows: Software for Canonical Community Ordination (version 4.5). Microcomputer Power (Ithaca, NY, USA)

Tockner K, Stanford JA (2002) Riverine flood plains: present state and future trends. Environ Conserv 29:308-330

Utermöhl H (1958) Zur Vervollkommung der quantitativen Phytoplankton-Methodik. Mitt. Internat.Verein. Limnol 9:1-38

van Donk E, van de Bund WJ (2002) Impact of submerged macrophytes including charophytes on phyto-and zooplankton communities: allelopathy versus other mechanisms. Aquat Bot 72:261-274

van Donk E, Gulati RD, Iedema A, Meulemans JT (1993) Macrophyte-related shifts in the nitrogen and phosphorus contents of the different trophic levels in a biomanipulated shallow lake. Hydrobiologia 251:19-26

Ward JV, Tockner K, Arscott DB, Claret C (2002) Riverine landscape diversity. Freshw Biol 47:517-539 